\title{
Pro Disability Policy in Local Governments: Lessons from the Central Lampung Regency
}

\author{
Simon Sumanjoyo Hutagalung ${ }^{1}$, Dodi Faedlulloh ${ }^{1}$ \\ ${ }^{1}$ Universitas Lampung, Indonesia
}

\begin{abstract}
All local governments have the same responsibility and obligation in positioning themselves as institution that are friendly to persons with disabilities, including Central Lampung Regency in Lampung Province. There are two important research questions in this research; (1). What are the efforts made by the Central Lampung Regency government towards groups with disabilities? (2). What are the problems that occur in the management of disability groups in Central Lampung Regency? The type of this research is descriptive with a qualitative approach. The data used by researchers in this study are sourced from primary and secondary data. In this study, primary data obtained through interview techniques was carried out by giving several questions related to the problem issues in research to the informants who had been determined. Informants in this study was collected with a purposive sampling technique. The key informants in this study were 9 heads of local government organizations, 10 representatives of community organizations, and 5 members of the regional parliament. All of them play a role in data collection activities which include focus group discussions, in-depth interviews, observation, and documentation. Meanwhile, data analysis was carried out using interactive data analysis techniques. In the last three years, the number of people with disabilities in Central Lampung has increased. However, the increase in the number of people with disabilities in Central Lampung is due to the expansion of the meaning and scope of disabilities in Indonesia regulation. It is known that several actions at the level of local government organizations in facilitating groups with disabilities can be designed in a more focused manner in the design of programs and policies covering the government, population and civil registration, social, health, education, employment, and transportation, and public infrastructure sectors.
\end{abstract}

Keywords: Disabilities Policy, Local Government, Social Protection, Colaboration

\section{Research Background}

Disability is an issue close to society because it is part of the human condition. Almost every human being has a disability at some stage in his life. For humans who reach a long life, there will be the possibility of experiencing the disability side due to difficulties in optimizing their physical and social functioning (Dirth \& Branscombe, 2017). Besides, there is the potential for mobility problems faced by aging persons? (Anand et al., 2020). Disability exists amid society, but often its existence is always in a position between being

Article history: Received: September, 2020; Revised: January, 2021; Accepted: January, 2021 
and not being. Persons with disabilities always experience great losses related to social and health determinants(Fortune et al., 2020).

Convention on the Rights of Persons with Disabilities which has been ratified by Indonesia in Law no. 19 of 2011 regulates various rights that must be fulfilled by state parties. The equalization policy for disabilities is inherently a human right (Lawson \& Beckett, 2020). These rights include the right to life, protection in situations of risk and emergency, equal recognition before the law, the right to be free and safe, free from pain and cruel treatment, freedom from exploitation, violence, and abuse, respect for privacy, freedom to live independently, the right to access personal mobility, access to information, respect for owning a home and family, participation in public and political life, freedom of expression, and other economic, social and cultural rights.

Based on reports from the World Health Organization (2015) persons with disabilities experience worse health and a higher level of health risk factors than nondisabled people. Based on the Inter-Census Population Survey (Supas) conducted by BPS (2015), it shows that the number of people with disabilities in Indonesia is 21.5 million. Meanwhile, from Sakernas data in 2016, it shows that the number of people with disabilities over the age of 15 is 22.8 million. In a more local context, Lampung Province based on information from the Indonesian Blind Association (Pertuni) in 2018 recorded that there were 20 thousand people with disabilities. Meanwhile, the Lampung Province Social Service recorded the number of people with disabilities at 17,800 .

Lampung Provincial Government has issued Perda No. 10 of 2013 concerning Services and Fulfillment of the Rights of Persons with Disabilities. This is a worthy note to be appreciated to show that there is an initial step towards caring for local governments for people with disabilities. According to the Lampung Provincial Regulation Number, 10 of 2013 concerning Services and Fulfillment of the Rights of Persons with Disabilities, persons with disabilities are any person who has a physical and/or mental disability that can interfere or constitute an obstacle for him to carry out activities properly, which consists of persons with physical disabilities, persons with mental disabilities as well as persons with physical and mental disabilities.

The binary perspective between disabilities and non-disabilities can be trapped in problems in formulating theoretical discussions to policymaking (Vehmas \& Watson, 2014). People with disabilities are subjects, they are human beings who have the same rights. All local governments have the same responsibility and obligation in positioning themselves as areas that are friendly to persons with disabilities, including Central Lampung Regency.

There are 1233 person with disabilities in the Central Lampung region (BPS, 2019). We can see the official data reported by BPS as follows: 
Table 1. Number of Persons with Disabilities by District in Central Lampung

\begin{tabular}{|c|c|c|c|c|}
\hline \multirow{2}{*}{ No. } & \multirow{2}{*}{ District } & \multicolumn{3}{|c|}{ Years } \\
\hline & & 2016 & 2017 & 2018 \\
\hline 1 & Padang Ratu & 13 & 92 & 76 \\
\hline 2 & Selagai Lingga & 1 & 78 & 29 \\
\hline 3 & Pubian & 10 & 9 & 53 \\
\hline 4 & Anak Tuha & 8 & 31 & 42 \\
\hline 5 & Anak Ratu Aji & 8 & 28 & 28 \\
\hline 6 & Kalirejo & 9 & 110 & 110 \\
\hline 7 & Sendang Agung & 11 & 76 & 55 \\
\hline 8 & Bangun Rejo & 14 & 22 & 31 \\
\hline 9 & Gunung Sugih & 17 & 77 & 86 \\
\hline 10 & Bekri & 1 & 37 & 38 \\
\hline 11 & Bumi Ratu Nuban & 3 & 14 & 13 \\
\hline 12 & Trimurjo & 14 & 25 & 39 \\
\hline 13 & Punggur & 11 & 21 & 28 \\
\hline 14 & Kota Gajah & 4 & 23 & 29 \\
\hline 15 & Seputih Raman & 3 & 89 & 57 \\
\hline 16 & Terbanggi Besar & 22 & 29 & 38 \\
\hline 17 & Seputih Agung & 26 & 22 & 43 \\
\hline 18 & Way Pengubuan & 6 & 12 & 19 \\
\hline 19 & Terusan Nunyai & 4 & 7 & 11 \\
\hline 20 & Seputih Mataram & 12 & 16 & 37 \\
\hline 21 & Bandar Mataram & 4 & 107 & 88 \\
\hline 22 & Seputih Banyak & 6 & 48 & 53 \\
\hline 23 & Way Seputih & 7 & 35 & 36 \\
\hline 24 & Rumbia & 5 & 30 & 43 \\
\hline 25 & Bumi Nabung & 4 & 14 & 20 \\
\hline 26 & Putra Rumbia & 3 & 24 & 29 \\
\hline 27 & Seputih Surabaya & 21 & 79 & 59 \\
\hline 28 & Bandar Surabaya & 19 & 29 & 43 \\
\hline & Total & 266 & 1184 & 1233 \\
\hline
\end{tabular}

Source: BPS (2019)

\section{Literature Review}

According to Law Number 19 of 2011 concerning the Ratification of the Rights of Persons with Disabilities, persons with disabilities are people who have long-term physical, mental, intellectual, or sensory limitations who is interacting with the environment and the attitudes of the community can encounter obstacles that make it difficult to fully participate (Wardana \& Dewi, 2017). According to the Lampung Provincial Regulation Number 10 of 2013 concerning services and fulfillment of the rights of 
disabilities, persons with disabilities are any person who has a physical and/ or mental disability that can interfere or constitute an obstacle for him to carry out activities properly, which consists of persons with physical disabilities, persons with mental disabilities as well as persons with physical and mental disabilities. People with special needs (disabilities) are people who live with special characteristics and have differences from people in general. Because these different characteristics require special services so that they get their rights as humans who live on this earth. People with special needs have a very broad definition, including people with physical disabilities, or low IQ (Intelligence Quotient) abilities, as well as people with very complex problems, so that their cognitive functions are impaired (Shakespeare, 2017). There are several types of people with special needs/disabilities. This means that every person with disabilities has their definitions, all of which need help to grow and develop properly. The types of persons with disabilities consist of mental disabilities, physical disabilities, and multiple disabilities. Mental disability is a form of mental disorder that consists of: (a). Mental High. Often known as intellectually gifted people, in addition to having intellectual abilities above average they also have creativity and responsibility for tasks, (b). Low Mental. Low mental abilities or intellectual capacity / IQ (Intelligence Quotient) below average can be divided into 2 groups; slow learners, a children who have an IQ (Intelligence Quotient) between 70-90. Meanwhile, children who have an IQ (Intelligence Quotient) below 70 are known as children with special needs, (c). Having Specific Learning Difficulties. Learning difficulties are related to learning achievement (achievement) obtained.

Meanwhile, physical disabilities are abnormalities in the body or individual physical which include: (a). Body Disorders (Tuna Daksa). Disability is an individual who has movement disorders caused by neuromuscular disorders and bone structure that are congenital, sick, or due to accidents (loss of body organs), polio, and paralysis, (b). Sense of Vision (Blind). Blind people are individuals who have visual impairments. Blindness can be classified into two groups, namely: total blindness (blind) and low vision. (c). Hearing Disorders (Deaf). Deaf people are individuals who have permanent or non-permanent hearing impairments. Because they have a hearing impairment, deaf individuals have a speech impediment, so they are usually called hearing impairment, (d). Speech Disorders, is someone who has difficulty expressing thoughts through verbal language so that it is difficult or even cannot be understood by others. This speech disorder can be understood by other people. This speech disorder can be functional, which is probably caused by hearing loss, and organic which is due to the imperfection of the speech organs as well as the motor organs related to speech. The last type is multiple disabilities, namely people with more than one disability (i.e. physical and mental disabilities). This speech disorder can be functional, which is probably caused by hearing loss, and organic which is due to the imperfection of the speech organs as well as the motor organs related to speech. The last type is multiple disabilities, namely people with more than one disability (i.e. physical and mental disabilities). This speech disorder can be functional, which is probably caused 
by hearing loss, and organic, which is due to the imperfection of the speech organs as well as the motor organs associated with speech. The last type is multiple disabilities, namely people with more than one disability (i.e. physical and mental disabilities) (Cieza et al., 2018).

Related to the concept of disability, Vehmas, and Makela in Prasetyo (2014) explained clearly that the perspective of social construction is the basis of ontology and epistemology in disability studies. The social construction paradigm provides the right criticism to reinterpret disability as something that is much more complex, not just an individual's biological condition, but there are external factors outside of people with disabilities, such as the social environment that contributes as a factor that complicates the situation of people with disabilities (Halimatussadiah et al., 2017). Thus, disability is the result of the interaction of limitations experienced by a person with his/her environment, not only physically or mentally, but is a multi-dimensional phenomenon that is intertwined with bodily functions, limited activity, barriers to participation and environmental factors (Huripah, 2020).

In the Indonesian context, problems often faced by persons with disabilities in Indonesia include lack of access to information on the importance of rehabilitation (Bella \& Dartanto, 2018), lack of public facilities that make it easier for persons with disabilities to carry out their daily activities (Nurhayati, 2020), and lack of access to jobs for persons with disabilities (Hikmawati \& Rusmiyati, 2011). In Indonesia alone, the number of persons with disabilities who can access education and work is still below $30 \%$. Various public services, public facilities, and public spaces have not been fully enjoyed by persons with disabilities (Priscyllia, 2016).

There are several categories of persons with disabilities regulated in Article 4 of Law no. 8 of 2016 concerning Persons with Disabilities, namely: (1). Persons with physical disabilities are impaired function of movement, including amputation, stiffness, paraplegia, cerebral palsy (CP), due to stroke, leprosy, and small people, (2). People with intellectual disabilities are impaired thinking because their intelligence level is below average, including slow learning, mental disability, and Down syndrome, (3). Mental disabilities are impaired in thinking, emotional and behavioral functions, among others; a) psychosocial including schizophrenia, bipolar disorder, depression, anxiety, and personality disorders; b) developmental disabilities that affect social interaction skills, including autism and hyperactivity.

However, in life, there are also persons with disabilities who experience multiple disabilities, namely having two or more types of disabilities. Both persons with physical, mental, and multiple disabilities as part of citizens have the same rights in the constitution. Therefore, the government is obliged to ensure the availability of health 
service facilities and facilitate persons with disabilities to be able to live independently and productively socially and economically.

\section{Research Method}

The type used in this research is descriptive with a qualitative approach. This qualitative research is also used for several considerations. First, this study places the relationship between researchers and informants as an important requirement. Second, this study is more sensitive to social phenomena and is better able to adjust or enhance the phenomena that occur in the research location (Moleong, 2012: 6). This research was conducted to identify and analyze the implementation of government agencies roles, for example social program or action to empowering persons with disabilities in Central Lampung.

The data used by researchers in this study are sourced from in-depth interview, documentation study and focus group disscusion. Those techniques was carried out by giving several questions related to the problem and issues of disability policy and program in the informants institution who had been determined. The data that has been obtained can be recorded or recorded by researchers (Sarwono, 2006: 209). Informants in this study include; Head of Social Service, Head of Population Service, Head of Health Service, Head of Education Office, Head of Research and Development Agency, Head of Regional Hospital, two leaders of a disability foundation in Central Lampung and 5 persons with disabilities from disability organizations also 5 regional legislators.

Informants in this study was collected with a purposive sampling technique. Purposive sampling technique is a purposive sampling technique with certain considerations (Sugiono, 2014: 218). All of the informant play an active role in data collection activities which include focus group discussions, in-depth interviews, observation, and documentation (Suwartono, 2014: 41). Meanwhile, data analysis was carried out using interactive data analysis techniques by Miles and Huberman which included reduction, presentation, verification, and conclusion (Sugiono, 2014: 247).

\section{Results and Discussion}

The Central Lampung Regency should be involved in community welfare efforts such as directly providing various forms of basic services such as education services and other public services. But back to reality, that there are so many obstacles, difficulties, restrictions, reduction, and even deprivation of rights for persons with disabilities in fulfilling their rights (Singsa et al., 2019). In this sub-study, the conditions of persons with disabilities will be explained as well as the conditions of policies and public services that have occurred in Central Lampung Regency. It is designed to see comprehensively all the resources that Central Lampung Regency has in dealing with disabilities. Even though there is still a lot of homework to do, however, the local government needs to build an optimistic outlook. Because the issue of disability is an issue that will always be contextual 
and actual. A pessimistic perspective will not produce anything, except for conditions of vulnerability for persons with disabilities (Huripah, 2020).

Based on BPS data in table 1, increasing on the number of disabilities from 2016 to 2017 has increased fourfold. The official document does not explicitly explain the reasons for the increase in this figure. However, if you look at the context of the birth of the latest regulation, the increase in the number of people with disabilities in Central Lampung is due to the expansion of the meaning and scope of disabilities. The three subdistricts that have the most people with disabilities are Kalirejo (110 people), Bandar Mataram (88 people), and Gunung Sugih (86 people). These sub-districts still lack the infrastructure that is friendly to persons with disabilities.

\subsection{Disability institutional support has not been optimal}

The conditions in Central Lampung are still many disabilities who have not been exposed and registered. In this case, it is because there are still cultural problems that become obstacles. There are still many families of persons with disabilities who object to attendance, for example, their children who are disabled, are known by the community. This is shown when a guest visits, the child with a disability is asked to enter the room so that it is not seen by others. Persons with disabilities are still considered a disgrace, therefore they are not worthy of being seen by the public view. This perception contradicts with the condition of the surrounding environment which is still trapped in the view of formalism, namely an understanding that worships normality, people with disabilities get a discriminatory response (Rahayu \& Dewi, 2013). In this context, of course, it will be a long task that must be carried out by the Central Lampung Regency in providing comprehensive education to the public about the importance of respecting and respecting the rights of persons with disabilities. This will be a tough job, because, considering the current condition, the offices in Central Lampung do not yet have data access as well as policies or programs for persons with disabilities, except only the Social Service. This condition conditions of persons with disabilities to be understood well by the social services (although this understanding is not necessarily comprehensive), but other regional apparatus organizations still do not have the same understanding (Fairuz \& Meliana, 2017). This creates a sectoral treatment, which is why it is very limited. The perspective that people with disabilities are the sole responsibility of the social service, cannot solve the problem more fully. This conditions the possibility of limited programs being trapped in the routine (Hidayat et al., 2019).

Cooperation between local government organizations in terms of persons with disabilities in Central Lampung Regency has not been integrated, so that when a policy or program is implemented it is always sectoral. There is no collaboration due to several factors, especially cultural factors, institutional factors, and political factors. Related to cultural factors is that collaboration can fail due to a cultural tendency to depend on procedures and not dare to make breakthroughs and risks (Kiling et al., 2019). To create 
effective collaboration, it requires public servants to have the expertise and willingness to partner pragmatically, that is, results-oriented. Dependence on procedures and not taking risks is one of the obstacles to effective collaboration (Sudarmo, 2011). Each government organization moves and adheres to their respective procedures, even though problems related to persons with disabilities need to be responded to with a collaborative approach to involve multi-stakeholders.

The condition of the relations between public organizations in Central Lampung needs to be based on collaborative relationships. Several factors are usually used to indicate the level of successful collaboration. DeSeve (Sudarmo, 2011) explained that there are important items that can be used to measure the success of a network or collaboration in governance, which includes: 1 ). Networked structured type, describes the conceptual description of a relationship between one element and another that is united together which describes the physical elements of the network being handled. 2). Commitment to a common purpose. Commitment to a common purpose refers to the reason why a network must exist. 3). Trust among the participants. There is mutual trust among actors/participants who are connected in the network based on professional or social relationships; the belief that participants rely on information or efforts from other stakeholders in a network to achieve common goals. 4). Governance, includes mutual trust among the actors, some boundaries can be involved and who cannot be involved, and there are clear rules of the game that are mutually agreed upon, and freedom to determine how collaboration is carried out. 5). Access to authority. Access to power, namely the availability of clear standards (measures) and procedures that are widely accepted. 6). Distributive accountability/ responsibility, sharing governance (structuring, management, management together with other stakeholders) and sharing decisionmaking to all network members; and thus share the responsibility for achieving the desired results. 7). Information sharing, namely easy access for members, privacy protection, and limited access for non-members to the extent acceptable to all parties. 8). Access to, namely the availability of financial, technical, human, and other resources needed to achieve network goals.

Using DeSeve's explanation above, it can be explained in the context of the level of collaboration in Central Lampung in responding to the problems faced by persons with disabilities in accessing their basic rights. First, there is no networked structure in building collaborative institutional structures in formulating policies or mainstreaming programs for persons with disabilities. One another, public organizers do not yet have attachment and unity, they are still moving and running independently. Second, there is still no commitment to a common purpose among public organizations in Central Lampung. Each of the organization in a certain context may have commitments in terms of persons with disabilities, but this commitment is still a limited commitment of one institution/ organization. The implication, although both of us are trying to implement the policy of mainstreaming persons with disabilities, they are still separate (Frian et al., 2019). Third, 
because there was no mutual commitment, there was no trust among the participants. There is no mutual trust between the perpetrators. It should be remembered that mutual trust in this context is neither personal nor subjective, because as fellow employees in the Central Lampung Regency both know each other and have certain social capital, personally, each of the apparatus can know and trust each other. However, in the context of collaboration, this mutual trust has not yet been fulfilled. There must be trust based on mutual commitment. because there was no mutual commitment, in the end, there was no trust among the participants. There is no mutual trust between the perpetrators. It should be remembered that mutual trust in this context is neither personal nor subjective, because as fellow employees in the Central Lampung Regency both know each other and have certain social capital, personally, each of the apparatus can know and trust each other.

However, in the context of collaboration, this mutual trust has not been fulfilled. There must be trust based on mutual commitment. because there was no mutual commitment, in the end, there was no trust among the participants. There is no mutual trust between the perpetrators. It should be remembered that mutual trust in this context is neither personal nor subjective, because as fellow employees of the Central Lampung Regency both know each other and have certain social capital, personally, each of the apparatus can know and trust each other. However, in the context of collaboration, this mutual trust has not been fulfilled. There must be trust based on mutual commitment. because as fellow employees in the Central Lampung Regency both know each other and have certain social capital, personally, each of the apparatus can know and trust each other. However, in the context of collaboration, this mutual trust has not been fulfilled. There must be trust based on mutual commitment. because as fellow employees in the Central Lampung Regency, both know each other and have certain social capital, personally, each of the apparatus can know and trust each other. However, in the context of collaboration, this mutual trust has not been fulfilled. There must be trust based on mutual commitment (Panggabean, 2019).

Furthermore, the fourth, governance in the Central Lampung regency is implemented but is limited. Fifth, access to authority also works but is limited. Access to power, namely the availability of clear standardized procedures, is available to each government organization but not yet in a collaborative framework. This condition creates a sixth condition, namely the absence of distributive accountability/ responsibility, namely sharing governance and sharing much decision-making among network members; thereby sharing the responsibility for achieving the desired results. Seventh, the potential for information sharing that has been carried out by public officials and organizations in the Central Lampung Regency Government regarding persons with disabilities. Furthermore, each government organization has access to, namely the availability of financial, technical, human, and other resources needed to make policies 
for mainstreaming persons with disabilities. However, the resources owned are not connected to the resources owned by other government organizations.

\subsection{Provision of facilities that support disabilities}

As in general, Central Lampung Regency still has problems in handling disabilities. Facilities for people with special needs or disabilities in Central Lampung are generally still inadequate. Things that can be highlighted are for example in public infrastructure and infrastructure. There are still many offices of public organizations, as well as private offices in Central Lampung that do not have roads or ladders for wheelchairs or, if any, are still steep or less accessible, which still endangers persons with disabilities. There are still many public offices that do not provide special toilet facilities for persons with disabilities. There are still many public buildings that do not install guiding blocks in their surrounding areas. Special facilities such as special parking locations for persons with disabilities are almost non-existent.

With several notes, there have been several government organizations that provide special spaces for persons with disabilities in public services, such as the one implemented by the Central Lampung Regency Population and Civil Registry Office which built special facilities for persons with disabilities. In terms of service, persons with disabilities have also prioritized to get services. The population and civil registry office have a pick-up program or visits to homes of persons with disabilities related to population services such as making family cards. This is a step that needs to be appreciated and is worthy of being adopted elsewhere. Even if it is examined further, there are still some notes, because they are still not available, such as parking spaces and special toilets for persons with disabilities.

Furthermore, in the field of education services for persons with disabilities, the Social Service has provided packages A, B, and C specifically for persons with disabilities, but unfortunately they are still not well socialized so that the level of educational participation of persons with disabilities is still not optimal. The Social Service also has a place or orphanage that can accommodate persons with disabilities, namely: 1) Jolosutro Rehabilitation Home, 2) KH. Nur Kholis, 3) Panti Srikandi. Central Lampung also has several special schools (SLB), but the numbers and resources are still very limited. One of them is Kurnia Poncowati's special school. This school was built because there is a sense of concern for children with disabilities or Children with Special Needs (SLB). SLB Kurnia was established in 2015 based on the empathy of a teaching staff who was motivated to provide a special place to study for children with disabilities such as deaf, mentally disabled, disabled, and autistic. The establishment of this special school is a concrete form of public participation in building education for the community. SLB Kurnia was built on private land owned by the initiator named Yuli. SLB Kurnia students produce handicrafts that have been exhibited at the Lampung Province level through LKSN activities delivered in 2018. SLB Kurnia Poncowati has 56 students from various 
classifications of disabilities. The obstacles that special schools experience are the lack of teaching staff, facilities, and infrastructure so that the services provided are not optimal. For operations, SLB Kurnia only gets odd sources of funding without much attention. As an illustration, to pay the salaries of 14 teachers, SLB Kurnia only receives operational funds from the central government of Rp. 15 million per year. As for other needs, SLB Kurnia only has one donor who always provides boxed rice for students and teachers every Friday in the first week of every month. Then, to support children's development, Kurnia's special school equipment is still very minimal. In other words, SLB Kurnia still needs the attention of various other parties. This is certainly a separate note, considering that Kurnia Poncowati's special school departed from the initiation of a community that cares for people with disabilities. But unfortunately, government assistance is still very limited. Another thing that is an obstacle to the educational participation of persons with disabilities is cultural factors, there are still many parents who have not accepted the existence of $A B K$, so many do not get access to education to improve their abilities. The Health Office sees the need for special regulations at the local government level regarding disabilities followed by an adequate budget policy.

Although in Indonesia, especially in Central Lampung Regency, there has been no research on the level of health vulnerability for persons with disabilities, it is believed that at a certain level of disability, the level of vulnerability will be much higher than for nondisabled people. After all, health is a basic right of citizens. This means that if a citizen is unable to do so, then the state should fulfill it (LaRoche \& Dhita, 2017). Health services for persons with disabilities in Central Lampung also experience several obstacles. One of the fundamental things is the access of people with disabilities to health social security (BPJS). As acknowledged by the Central Lampung Social Service, from the data they have, it is still difficult for persons with disabilities in Central Lampung to get BPJS, so they have vulnerabilities in health. Another limitation, there is only one Central Lampung Mental Hospital. As an illustration, the hospital has 300 beds but is inhabited by 900 people. This shows the lack of facilities and infrastructure for persons with disabilities.

Health services will be more optimal if the health service unit is also disability friendly. For example, with the establishment of a Disability-Friendly Community Health Center, a health center that is expected to be able to provide a sense of comfort and safety as well as equal services for disabilities. Disability-friendly Puskesmas strive to fulfill the rights of persons with disabilities physically, healthily, and mentally. In this case, there are 39 health centers in Central Lampung, but they do not yet have comprehensive facilities that are disability-friendly such as; 1) Provision of special ramps for wheelchairs, 2) Running text to facilitate deaf disabilities when waiting in line, 3 ) Handrail, 4) Adaptive queue counters for wheelchairs, 5) Home pick-up program, 6) Special officers to serve persons with disabilities, and 6) Provision of wheelchair facilities at puskesmas. However, for hospital-scale service units, hospitals in Central Lampung have provided health services without discrimination. On the other hand, the Central Lampung Health Office 
already has a community-sourced rehabilitation program (RBM), home care whose goal is to get them to get health services.

Furthermore, the development and distribution of work for people with disabilities not in optimal condition. Based on regulation, in article 53 paragraph (1) Law No.8 of 2016 affirms that the Government, Regional Government, State-Owned Enterprises and Regional-Owned Enterprises are required to employ at least 2\% (two percent) of persons with disabilities of the number of employees or workers, and paragraph (2) Private companies are required to employ at least $1 \%$ (one percent) of persons with disabilities of the number of employees or workers. However, in its implementation, the Central Lampung Manpower Office said that the practice of mainstreaming in the quota format has not been going well. As an illustration, one of the big companies in Central Lampung, GGF (Great Giant Food) Company, when conducting surveillance and data collection, only 3 employees with disabilities, work in this company.

Public transportation in Central Lampung is still inadequate when viewed for the needs of persons with disabilities. Public transportation in Central Lampung is not friendly for people with disabilities. Besides, sidewalks also include public facilities that cannot yet meet the needs of persons with disabilities. Public transportation in Central Lampung still does not have supporting facilities that technically make it easy for passengers with disabilities. At the time of observation, public transportation such as inter-city buses and city transportation were not equipped with special facilities for persons with disabilities. Likewise, public facilities such as bus stop where public transportation stops are not equipped with special roads for persons with disabilities. As a result, In general, persons with disabilities still experience difficulties in accessing public transportation modes. Therefore they are still unable to fully carry out activities independently (Bezyak et al., 2017).

This condition shows that a special policy is needed regarding the prioritization of the rights of persons with disabilities in Central Lampung Regency so that it can become an imperative formal foundation so that all lines of government provide the best services to persons with disabilities (Notoprayitno \& Jalil, 2019). Another thing that needs to be further encouraged is a collaboration between government organizatio in the implementation of mainstreaming people with disabilities so that the work carried out is not sectoral (Anomsari \& Mursalim, 2020). On the other hand, so that policies to be formulated are right on target, it is necessary to collect further data on persons with disabilities. With specific and accurate data, the government and the public will know in detail how many people with disabilities of various types.

\subsection{Disability support policy agenda}

Persons with disabilities must be treated as part of citizenship (Kim, 2020). Citizens are the fundamentals of the state where the government is responsible for guaranteeing 
various interests. This view departs from the theory of democratic citizens, in which they want to be involved in governmental activities as a form of public altruism (Fikriyah, 2017). The implication of the view of persons with disabilities as citizens is that the active involvement of people with disabilities must be built. This involvement can be built through, (1) providing access to education-based information, open government, and free communication; (2) provide direct or indirect access to decision-making forums; (3) the ability to convey any issue in the public space; (4) the ability to claim rights without fear; (5) considering all incoming demands. In this case, the government needs to involve many elements to create opportunities as well as participation, collaboration, and community. In this context, Denhardt and Denhardt reminded us that government cannot create a community (Sriram et al., 2019). However, political leaders can build communities that work effectively and are accountable to citizens. The point is, citizens must know that government is open and accessible to anyone. Also so that citizens know that the government is responsive to their aspirations. However, political leaders can build communities that work effectively and are accountable to citizens. The point is, citizens must know that government is open and accessible to anyone. Also so that citizens know that the government is responsive to their aspirations (Stout, 2018). However, political leaders can build communities that work effectively and are accountable to citizens. The point is, citizens must know that government is open and accessible to anyone. Also so that citizens know that the government is responsive to their aspirations (Ningtyas, 2017).

In the policy implementation process, policy involvement is not limited to certain priority issues. Instead, they are involved in all stages of policymaking and implementation processes. So that through this process, said Denhardt, citizens "come to see themselves as citizens, rather than consumers, clients, and beneficiaries of the administrative state". In that context, the government and citizens are acting together to strive for and create public good. As Denhradt and Denhradt have explained, citizens are not only "customers", but "owners". Citizens are not like customers who choose what they want. On the other hand, citizens demand that the government provide something they think is important. On the other hand, the government is generally accountable to citizens as constituents (Strokosch \& Osborne, 2021).

The new public service paradigm is relevant in the context of preparing policies for mainstreaming the rights of persons with disabilities because this view sees that humans must be viewed as a whole (Percy, 2018). Humans have self-respect, trust, belonging, care, and service. These aspects are then synchronized with the New Public Service approach, namely, "respecting public service ideals". The ideals of the New Public Service include honesty, equality, responsiveness, respect, empowerment, and commitment. This is expected to be the basis for the formation of policies that protect groups with disabilities at the regional level.

\section{Conclusion}


It is known that in the last three years, the number of people with disabilities in Central Lampung Regency has increased. The increase in the number of disabilities from 2016 to 2017 has increased fourfold. The official document does not explicitly explain the reasons for the increase in this figure. However, if you look at the context of the birth of the latest regulations, the increase in the number of people with disabilities in Central Lampung is due to the expansion of the meaning and scope of disabilities. The three subdistricts that have the most people with disabilities are Kalirejo (110 people), Bandar Mataram (88 people), and Gunung Sugih (86 people). It is known that several actions at the level of local government organizations in facilitating groups with disabilities can be designed in a more focused manner in the design of programs and policies covering the government, population and civil registration, social, health, education, employment, and transportation, and public infrastructure sectors. The scope of these measures includes physical infrastructure that facilitates access and performance of groups with disabilities and program interventions that seek to increase their capacity in carrying out public activities.

The problems faced are more dominant in the aspect of policy commitment from the central government in allocating budget assistance and strengthening the participation of groups with disabilities in local government programs, especially those that have a direct impact on their welfare.

\section{Bibliography}

Anand, P., Roope, L. S. J., Culyer, A. J., \& Smith, R. (2020). Disability and multidimensional quality of life: A capability approach to health status assessment. Health Economics (United Kingdom), 29(7), 748-765. https://doi.org/10.1002/hec.4017

Anomsari, E. T., \& Mursalim, S. W. (2020). Mainstreaming Disability: Challenges and Strategies Toward Equality and Decent Work in Indonesia | Soshum: Jurnal Sosial dan Humaniora. http://ojs.pnb.ac.id/index.php/SOSHUM/article/view/1444

Bella, A., \& Dartanto, T. (2018). Persons with disabilities (PWD) and poverty in Indonesia. Malaysian Journal of Economic Studies, 55(2), 167.

Bezyak, J. L., Sabella, S. A., \& Gattis, R. H. (2017). Public Transportation: An Investigation of Barriers for People With Disabilities. Journal of Disability Policy Studies, 28(1), 5260. https://doi.org/10.1177/1044207317702070

Cieza, A., Sabariego, C., Bickenbach, J., \& Chatterji, S. (2018). Rethinking Disability. BMC Medicine, 16(1), 14. https://doi.org/10.1186/s12916-017-1002-6

Dirth, T. P., \& Branscombe, N. R. (2017). Disability Models Affect Disability Policy Support through Awareness of Structural Discrimination. Journal of Social Issues, 73(2), 413442. https://doi.org/10.1111/josi.12224

Fairuz, F. S., \& Meliana, M. D. (2017). Implementation Of Public Facilities And Disability Treatments: A Comparison Between Indonesia And Malaysia. 11-15. https://doi.org/10.2991/icddims-17.2018.3 
Fikriyah, U. (2017). Legal protection of right of education for persons with disability in Indonesia and islamic law. Legal Protection of Education Right for Person with Disability in Indonesia Compared to Islamic View. 124-132. https://doi.org/10.2991/icddims-17.2018.26

Fortune, N., Badland, H., Clifton, S., Emerson, E., Rachele, J., Stancliffe, R. J., Zhou, Q., \& Llewellyn, G. (2020). The Disability and Wellbeing Monitoring Framework: Data, data gaps, and policy implications. Australian and New Zealand Journal of Public Health, 44(3), 227-232. https://doi.org/10.1111/1753-6405.12983

Frian, A., Mulyani, F., Joachim, H., Anggreni, D., \& Effendi, W. Y. (2019, January 5). Employment Situation of Person with Disabilities: Case Study in Indonesia [MPRA Paper]. https://mpra.ub.uni-muenchen.de/91576/

Halimatussadiah, A., Nuryakin, C., Muchtar, P. A., Bella, A., \& Rizal, H. (2017). Mapping Persons with Disabilities (PWDs) in Indonesia Labor Market. Economics and Finance in Indonesia, 63(2), 126-149. https://doi.org/10.47291/efi.v63i2.572

Hidayat, H. N., Pramono, Meigalia, E., Saddhono, K., \& Anwar, K. (2019). INCOLWIS 2019: Proceedings of the 2nd International Conference on Local Wisdom, INCOLWIS 2019, August 29-30, 2019, Padang, West Sumatera, Indonesia. European Alliance for Innovation.

Hikmawati, E., \& Rusmiyati, C. (2011). Kebutuhan Pelayanan Sosial Penyandang Cacat. Jurnal Informasi, 16(1), 18.

Huripah, E. (2020). Towards an Inclusive Social Welfare Institution for Disabilities: The Case of Indonesia. Asian Social Work Journal, 5(1), 18-28. https://doi.org/10.47405/aswj.v5i1.122

Kiling, I., Due, C., Li, D., \& Turnbull, D. (2019). Perceptions of disability, environmental risk factors and available services among local leaders and parents of young children with disabilities in West Timor, Indonesia. Disability and Rehabilitation, 41(20), 2421-2432. https://doi.org/10.1080/09638288.2018.1466924

Kim, Y. (2020). Child Welfare Service Reform in Nebraska and New Public Service (NPS). Student Research and Creative Activity Fair. https://digitalcommons.unomaha.edu/srcaf/2020/schedule/71

LaRoche, D., \& Dhita, F. (2017). A qualitative investigation of the healthcare challenges of women with disabilities in Yogyakarta (Indonesia): Implication for health policy. https://doi.org/10.26021/9527

Lawson, A., \& Beckett, A. E. (2020). The Social and Human Rights Models of Disability: Towards a Complementarity Thesis. International Journal of Human Rights, 0(0), 132. https://doi.org/10.1080/13642987.2020.1783533

Ningtyas, T. (2017). New Public Service: Pelayanan Publik Berbasis Humanistik untuk Kesuksesan Reformasi Birokrasi. Jurnal Ilmiah Manajemen Publik Dan Kebijakan Sosial, 1(1), 13-22. https://doi.org/10.25139/jmnegara.v1i1.283

Notoprayitno, M. I., \& Jalil, F. (2019). Legal Aspect of Inclusive Education for Persons with Disabilities in Indonesia (SSRN Scholarly Paper ID 3502170). Social Science Research Network. https://papers.ssrn.com/abstract=3502170 
Nurhayati, S. (2020). Social Inclusion For Persons With Disabilities Through Access To Employment In Indonesia. Prophetic Law Review, 2(1), 1-21. https://doi.org/10.20885/PLR.vol2.iss1.art1

Panggabean, S. N. (2019). Access of People with Disabilities to Justice in Indonesia General Court System. IJDS:INDONESIAN JOURNAL OF DISABILITY STUDIES, 6(1), 95-101. https://doi.org/10.21776/ub.ijds.2019.006.01.13

Percy, S. L. (2018). Disability, Civil Rights, and Public Policy: The Politics of Implementation. University of Alabama Press.

Prasetyo, F. A. (2014). Disabilitas Dan Isu Kesehatan: Antara Evolusi Konsep, Hak Asasi, Kompleksitas Masalah, dan Tantangan. Buletin Jendela Data Dan Informasi Kesehatan, II, 31-40.

Priscyllia, F. (2016). Kajian Hukum Terhadap Fasilitas Pelayanan Publik Bagi Penyandang Disabilitas. Lex Crimen, V(3), 105-112.

Rahayu, S., \& Dewi, U. (2013). Pelayanan Publik Bagi Pemenuhan Hak-Hak Disabilitas di Kota Yogyakarta. Natapraja, 1(1).

Shakespeare, T. (2017). Disability: The Basics. Routledge.

Singsa, A., Sriyakul, T., Sutduean, J., \& Jermsittiparsert, K. (2019). Willingness of Supply Chain Employees to Support Disability Management at Workplace: A Case of Indonesian Supply Chain Companies. Journal of Computational and Theoretical Nanoscience, 16(7), 2982-2989. https://doi.org/10.1166/jctn.2019.8205

Sriram, N., Misomnai, C., Metasuttirat, J., \& Rajphaetyakhom, C. (2019). A Comparative Analysis of New Public Management New Public Service and New Public Governance (SSRN Scholarly Paper ID 3553641). Social Science Research Network. https://papers.ssrn.com/abstract=3553641

Stout, M. (2018). The impossibility of a universal public service perspective. Teaching Public Administration, 36(3), 222-236. https://doi.org/10.1177/0144739417738953

Strokosch, K., \& Osborne, S. P. (2021). Co-production from a Public Service Logic Perspective. In E. Loeffler \& T. Bovaird (Eds.), The Palgrave Handbook of CoProduction of Public Services and Outcomes (pp. 117-131). Springer International Publishing. https://doi.org/10.1007/978-3-030-53705-0_6

Sudarmo. (2011). Issu-Issu Administrasi Publik Dalam Perspektif Governance. Smart Media.

Vehmas, S., \& Watson, N. (2014). Moral Wrongs, Disadvantages, and Disability: A Critique of Critical Disability Studies. Disability and Society, 29(4), 638-650. https://doi.org/10.1080/09687599.2013.831751

Wardana, A., \& Dewi, N. P. Y. P. (2017). Moving Away From Paternalism: The New Law on Disability in Indonesia. Asia-Pacific Journal on Human Rights and the Law, 18(2), 172195. https://doi.org/10.1163/15718158-01802003

World Health Organization. (2015). WHO Global Disability Action Plan 2014-2021. Better Health for All People with Disability. 